\title{
Genetics of male infertility: Indian scenario
}

\author{
K Thangaraj \\ From International Conference on Human Genetics and 39th Annual Meeting of the Indian Society of \\ Human Genetics (ISHG) \\ Ahmadabad, India. 23-25 January 2013
}

According to the recent epidemiological studies, nearly one out of every 10 couples face a problem in conceiving a child. Impaired fertility of male partner is causative in approximately $50 \%$ of all couples unable to conceive spontaneously. We have been studying the genetic factors associated with male infertility among Indian population. We have earlier shown that about $8.5 \%$ infertility among Indian men is due to the $\mathrm{Y}$ chromosome microdeletions. Further analysis of several autosomal (NR5A1, KLK3, CETN1, DEFB126, CAMK4, UBE2B, TNP1 \& 2 and PRM1, 2 \& 3); Y chromosomal (DAZ deletions, TSPY1 copy number) and mitochondrial genes accounted for additional $19.5 \%$ of the genetic factors responsible for male infertility. However, etiology of a large proportion (72\%) of infertile men still remains unknown. Gene expression studies from our lab using microarray approach, showed several genes are many folds down regulated in the testicular tissue of infertile men, compared to the fertile men. Targeted resequencing of these differentially expressed genes and functional characterization of the observed mutations is in progress. In addition, we have recently initiated exome sequencing of idiopathic male infertile samples to identify additional genetic factors responsible for male infertility. The results of the findings would be discussed at the time of presentation.

Submit your next manuscript to BioMed Central and take full advantage of:

- Convenient online submission

- Thorough peer review

- No space constraints or color figure charges

- Immediate publication on acceptance

- Inclusion in PubMed, CAS, Scopus and Google Scholar

- Research which is freely available for redistribution

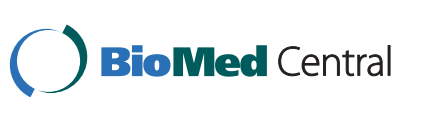

(C) 2014 Thangaraj; licensee BioMed Central Ltd. This is an Open Access article distributed under the terms of the Creative Commons Attribution License (http://creativecommons.org/licenses/by/2.0), which permits unrestricted use, distribution, and reproduction in any medium, provided the original work is properly cited. The Creative Commons Public Domain Dedication waiver (http:// creativecommons.org/publicdomain/zero/1.0/) applies to the data made available in this article, unless otherwise stated. 